\title{
Competitive Advantage Through Taxation In GCC Countries
}

Humoud Almutairi, Kuwait University, Kuwait

\begin{abstract}
This study analyzes and compares the competitive advantage of taxation for six members of the Gulf Co-operation Council (GCC): Bahrain, Kuwait, Oman, Qatar, Saudi Arabia, and the United Arab Emirates. The GCC countries enjoy one of the least demanding tax systems in the world. The average total tax rate for the entire Middle East region is 23.6\%, which is much less than the global average of $44.7 \%$. Thus, the taxation structure and system of the GCC nations is uncomplicated when compared to rest of the world. Moreover, the GCC nations depend heavily on indirect taxes and revenue from energy exports, rather than internally generated funds. Though this system has its advantages, it may become a cause of concern for authorities in the future as taxation can influence the overall growth in different dimensions. Thus, this study further explores the need for an effective taxation policy to support future performance of the GCC member nations.
\end{abstract}

Keywords: GCC Nations; Value-Added Tax; Competitive Advantage

\section{INTRODUCTION}

The hardest thing to understand in the world is income taxes. - Albert Einstein

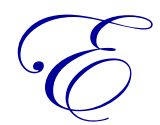

conomists worldwide project another downturn for the world economy, which is teetering as a result of years of anemic and uneven recovery from the global financial crisis. The years 2011 and 2012 registered a comparably low output from most developed countries and the forecast for 2013 is not different. These results have intensified the gloom over continued job crisis in most developed economies and will certainly impact the income growth of developing nations. Thus, a serious, renewed global downturn is looming because of persistent weaknesses in major developed economies from problems like the job crisis and declining prospects of economic growth, which have been left unresolved in the aftermath of the Great Recession of 20082009.

The global economic growth dropped to almost $3 \%$ in 2012, shaving off about half a percentage point from the long-term trend since the crisis emerged (Elecon Engineering Company Limited, 2012). Uncertainty across the regions - from the post-election 'fiscal debate' in the U.S. to the transition in Chinese leadership, and reforms in the Euro Area - will continue to impact the sluggish trade and tepid foreign direct investment globally. As the Middle East region depends heavily on revenue from oil exports, any bad news related to the world economy may adversely affect its crude oil prices. Alternatively, a tight and real relation between oil and recession is evident from the observed increase in oil prices with the "rebound" in the U.S. economy since December 2008. In view of the above scenario, it is clear that GCC nations are not immune to the impact of the global economy, and thus the governments of GCC nations may need to find new sources of funding for their smooth functioning. In this direction, this study: 1) provides the historical outlook on development of taxation issues in GCC nations and 2) closely examines the competitive advantages of taxation in GCC nations.

\section{HISTORICAL OVERVIEW}

The taxation issue in the GCC states dates back to its inception in the late 1980's. Previously, Kuwait had introduced a corporate tax in 1955 and Saudi Arabia levied income tax on foreigners until 1975. Though Saudi 
Arabia suspended its tax in 1975 because of the increase in its oil revenues, and the need to recruit large numbers of foreign workers to help develop its economy and infrastructure, the tax was reintroduced in 1988 to offset the declining oil revenues.

In 1985, the government of Bahrain tried to introduce personal or corporate taxes, but faced great opposition, as at the time it was "an idea which all the peoples of the area regarded as dangerously socialist and thoroughly un-Arabian" (Field, 1985).

The representatives of the GCC states performed a feasibility study in the early 1990's on introducing Value Added Taxes (VAT) and Corporate Taxes as part of their economic reforms. On the basis of this study, Oman introduced a corporate tax in 1994, which later exempted certain sectors and projects, even though there was a continuous decline in the oil prices. However, most GCC states remained wary of implementing taxes for fear of upsetting international and domestic businesses and investors. A 1992 report on the Bahraini economy illustrated the wider regional situation when it noted, "Some modest - and heavily disguised - attempts have been introduced to boost tax revenues, but more direct methods, such as an income tax, are deemed to be politically impossible" (Mathew, 1992, 14 July).

By the early 1990's, international organizations, like the United Nations, Moody's, and the IMF, started to encourage the GCC states to implement taxation policies. In 1997, the annual report of the United Nations Economic and Social Commission for West Asia noted, "significant scope [in the GCC states]...to eliminate tariff exemptions, expand excise taxes, and introduce a selective tax on luxury goods...In addition, tax revenues could be increased by expanding the scope and coverage of the current income taxes." For Qatar, a 1998 report by credit ratings agency Moody's recommended, "If oil prices remain soft, the government will need to respond with corrective fiscal measures in order to contain unsustainably high budget deficits" (Global Credit Research, 1998). At the time, Qatar had no form of corporate taxation and subsidized the utility, health, and education sectors. In the year 2000, the Kuwaiti Finance Minister declared that Kuwaitis would have to get used to the idea of an income tax. However, along with other measures aimed at reforming the Kuwaiti economy, the proposal met fierce opposition in the country's parliament, despite the fact that some Kuwaitis suggested that they would not mind paying taxes if services improved as a result.

In addition, in 2000, in an attempt to attract increased foreign investment, Saudi Arabia and Oman announced tax reductions on foreign businesses. In 2001, an IMF report argued that GCC states could no longer rely on oil sales and recommended them to cut spending and implement income tax, corporate tax, consumption tax, and value-added tax. On a country-specific basis, IMF consultations noted Kuwait's efforts to reform its corporate income tax law whilst recommending, "The introduction of a broad-based consumption tax and the levying of excises on luxury items" (International Monetory Fund, 2001, 29 June). The IMF recommended that Saudi Arabia should "move ahead with steps to mobilize non-oil revenues through improvements in tax administration, early introduction of indirect taxes, and consolidation of various fees and charges" (International Monetory Fund, 2001, 07 November). In Qatar, the IMF “encouraged the authorities to reduce the budget's dependence on oil receipts through the gradual introduction of a modern tax system, based on a range of taxes on consumption and profits, to replace and broaden existing sources of non-oil revenue" (International Monetory Fund, 2002, 10 September). Recommendations for the UAE included adopting "a broad-based modern tax system with a view to reducing fiscal vulnerability...expand taxes in line with policies...already in place in other members of the GCC, and consider implementing a broad low-rate consumption tax on services while local governments should introduce a property tax. Several Directors encouraged the authorities to avail themselves of Fund technical assistance for tax reform and institution building" (International Monetory Fund, 2003, 11 March). IMF suggested that Oman should "adopt, in the short run, excise taxes on luxury goods and services and a simple property tax to replace the current scheme of taxation of rental agreements (International Monetory Fund, 2010, 17 February).

\section{THE REGIONAL (MIDDLE EAST) ANALYSES}

In the Middle East region, labor taxes and social contributions account for the largest part of the total tax rate, number of payments, and time to comply - a profile which is quite different from the average global profile. The element of labor taxes and social contributions is a common feature of economies in the region, apart from the 
West Bank and Gaza where no labor taxes are levied on the employer. It is also worth noting that a number of oilrich economies, commonly known as the GCC states (Kuwait, Qatar, Oman, Bahrain, Saudi Arabia, and the United Arab Emirates), continue to have little or no applicable corporate income tax, which explains the low overall average total tax rate. The absence of consumption and "other" taxes also helps explain this average rate.

The total tax rate has fallen by only 2.5\% for the region since Paying Taxes 2007 and has remained flat in the most recent years. Between Paying Taxes 2006 and 2007, the total tax rate fell from an average of 41.4\% to $28.1 \%$. This largely reflects the replacement of the production tax (which was a cascading tax) with a sales tax by the Republic of Yemen. This economy also reduced the rate of its corporate income tax from 35\% to 20\% in 2010. There has been no significant movement in the total tax rate for any of the Middle East economies in the most recent year.

In 2012, the Middle East experienced more turmoil than ever before. Totalitarian regimes tumbled and others may follow. The so-called Arab Spring has led to a change in the regimes in the Arab Republic of Egypt, Libya, Tunisia, and the Republic of Yemen where economic injustice and poverty are rampant. Even the oil rich countries observed some unsettling periods. However, such countries have taken swift measures to defuse difficult situations by providing economic stimulus packages and direct cash payments to citizens, while still relying on continued income from oil revenues. In less fortunate economies, governments have resorted to increased borrowing and taxes to finance necessary assistance for citizens.

Despite these major disturbing events, Middle Eastern governments have not made any drastic changes to their tax regimes so far which is reflected in the results of the Paying Taxes study. The indicators have been very stable and the total tax rate and time-to-comply indicators suggest that the region is the least demanding in terms of Paying Taxes. The region has retained a leading position in the study for a number of reasons. First, the introduction of new taxes and the study of their potential impact has been a long and slow process in the region. New taxes have not yet been introduced and the region is still characterized by low tax regimes with few taxes for domestic investors. Second, as the case study company is a wholly domestic company, it is interesting to note that corporate tax laws of most GCC countries (with the exception of Oman) tax foreign investors more heavily, while locallyowned entities are almost exempt from taxes. Finally, the compliance burden of GCC nations is at a level below the world average due to the lack of sales taxes and other indirect taxes.

The United Arab Emirates has the fourth best tax regime in the world - favorable for businesses - which has helped this country to be among the top in attracting foreign direct investment (FDI) during the global recession period, as per a new study. As per the report 'Paying Taxes 2010 - The Global Picture', UAE has one of the lowest total tax rates (TTR) among the top 10 economies and the compliance requirements for doing business are the simplest. The study was produced jointly by the World Bank Group, PricewaterhouseCoopers (PwC), and the International Finance Corporation (World Bank Group and PwC, 2013, 19 November).

Even though the immediate impact of recent events in the Middle East and the worldwide economic crisis has not directly translated into major changes in tax policies, generally, some new tax laws have been implemented by a few Middle Eastern countries, and it is most likely that other major changes will follow in the coming years. The most recent major changes worth mentioning here are new income tax laws in Qatar and Jordan, as well as new transfer pricing regulations in Egypt. We have also witnessed the introduction of an additional tax bracket for corporations and individuals with higher profits and income in Egypt, as well as a drafted budget law for 2013 in Lebanon, which will introduce an increase in corporate and individual tax rates, as well as an array of increases in indirect taxes (except VAT, which remains at 10\%).

With increased spending requirements and demand for greater economic rights by the populace, the governments in the Middle East will face a challenge to raise additional tax revenues in the future, either by introducing new taxes (for example VAT), expanding the tax base (by taxing corporations owned by citizens), or increasing the tax rates (as some countries have already started to do). The GCC countries also continue to endeavor to introduce a VAT system within the next two to four years. With a slowing world economy and the potential stagnation in oil prices, governments in both oil and non-oil rich countries will need to increase tax revenues to balance their budgets and, at the same time, still provide an attractive business environment for investors. In all of this, only one thing is certain - that change is inevitable in the Middle East. 
A customs union with a free trade area, along with a common external tariff, was formed in 2003, which has been instrumental in successful removal of overt trade barriers within the GCC. To date, the full functioning of the project did not take place due to the disagreements on the division of customs revenues between the governments. A customs union authority was set up to complete the revenue sharing debate, which is expected to get finalized in 2014. Options include dividing revenue from customs according to the level of imports, population, or the share of gross domestic product of individual countries, a GCC official said in October.

\section{COMPETITIVE ADVANTAGE}

Competitive advantage is the ability gained through attributes and resources to perform at a level higher than others in the same industry or market (Lynch, 1999). The study of competitive advantage has attracted profound research interest due to contemporary issues related to superior performance levels of firms in the present competitive market conditions. "A firm is said to have a competitive advantage when it is implementing a value creating strategy, not simultaneously being implemented by any current or potential player" (Barney, 1991). The same principle is applicable even for a state. Successfully implemented strategies will lift a country to superior performance by facilitating the country with competitive advantage to outperform.

Table 1 compares several variables that may influence the competitive advantage of the GCC nations. According to this analysis based on the 2008-2009 report by PwC, tax rates are the least problematic of the factors for doing business in GCC countries. Thus, the competitive advantage of tax rates and tax regulations for GCC countries is well-evident when compared to other variables.

Table 1: Comparative Competitive Advantage of GCC Countries from a Business Perspective

\begin{tabular}{|c|c|c|c|c|c|}
\hline \multirow{2}{*}{ Hindrance Factors In Doing Business } & \multicolumn{5}{|c|}{ Rank } \\
\hline & KSA & Bahrain & Kuwait & Oman & Qatar \\
\hline Inadequately educated workforce & 1 & 3 & 4 & 2 & 4 \\
\hline Inflation & 2 & 5 & 6 & 3 & 2 \\
\hline Restrictive labor regulations & 3 & 1 & 2 & 1 & 1 \\
\hline Inefficient government bureaucracy & 4 & 2 & 1 & 5 & 5 \\
\hline Access to financing & 5 & 9 & 5 & 6 & 6 \\
\hline Inadequate supply of infrastructure & 6 & 4 & 7 & 4 & 3 \\
\hline Corruption & 7 & 7 & 3 & 8 & 8 \\
\hline Crime and theft & 8 & 10 & 13 & 13 & 14 \\
\hline Foreign currency regulations & 9 & 8 & 12 & 9 & 7 \\
\hline Poor public health & 10 & 14 & 11 & 14 & 9 \\
\hline Policy instability & 11 & 6 & 8 & 7 & 10 \\
\hline Tax rates & 12 & 13 & 14 & 11 & 12 \\
\hline Tax regulations & 13 & 12 & 10 & 10 & 13 \\
\hline Government instability & ----- & 11 & 9 & 12 & 11 \\
\hline
\end{tabular}

Source: Processed from Global Competitiveness Report 2008-2009 (PwC \& IFC)

As per the Global Competitiveness Report 2008-2009 by Klaus Schwab of the World Economic Forum and Michael E. Porter of Harvard University, the GCC countries view taxes as one of the least problematic factors for doing business (Klaus Schwab, 2008). In the case of United Arab Emirates, the most problematic factors are inflation, restrictive labor regulations, inadequate educated workforce, etc. For them, tax rates become a problem only next to poor public health and corruption (Figure 1: UAE Global Competitiveness in Annexure). In the case of Saudi Arabia, being the largest among the GCC Countries, inadequate educated work force, inflation, and restrictive labor regulation stand as the first three main blockades in doing business. For them, too, tax rates are not a very significant problem (Figure 2: KSA Global Competitiveness in Annexure). As per this report, Bahrain has major problems with the restrictive labor regulations, inefficient government bureaucracy, and the lack of adequate educated work force. For them, tax regulation does not seem to be problematic at all (Figure 3: Bahrain Global Competitiveness in Annexure). In the case of oil rich Kuwait, the inefficient government bureaucracy, restrictive labor regulations, and corruption tops the chart as the most problematic factors for doing business. Tax rates seem not at all significant (Figure 4: Kuwait Global Competitiveness in Annexure) In the case of the Sultanate of Oman, restrictive labor regulations, inadequate educated workforce, and inflation are the major obstacles in doing business. 
The tax rates are overlooked and do not seem to be a problem at all (Figure 5: Oman Global Competitiveness in Annexure). In the case of Qatar, like many of its fellow GCC countries, restrictive labor regulations, inflation, and inadequate supply of infrastructures are the major hindrances in doing business. Tax rates do not bother them (Figure 6: Qatar Global Competitiveness in Annexure) (Klaus Schwab, 2008).

Moreover, according to a new report compiled by the World Bank, International Financial Corporation (IFC), and PricewaterhouseCoopers (PwC), companies in the UAE enjoy the world's least demanding tax framework. In the ranking of countries with the lightest administrative burden in terms of tax payments, Qatar and Saudi Arabia are ranked second and third, respectively, whereas Bahrain, Oman, and Kuwait stand 7th, 10th, and 11th, respectively (Soumitra Dutta, 2012).

Companies operating in the UAE, which was ranked sixth globally last year for the easiest tax structure, pay an annual total tax rate of $14.9 \%$, make four payments a year, and spend just four hours in administrative preparations for payments, said the report. The UAE is among the few countries in the world without a personal income tax regime. In April this year, the UAE Minister of Finance and Deputy Ruler of Dubai, Shaikh Hamdan bin Rashid Al Maktoum, reiterated that the country has no plans to impose income tax or new service fees on individuals and companies to fund any fiscal deficit.

The Paying Taxes 2013 study analyzes the tax regimes of 185 economies, including 13 Middle Eastern countries, and finds that companies in the Middle East pay a total average tax rate of $23.6 \%$ compared to a global average of $44.7 \%$ - the lowest of any region in the world. On average, a medium company in the Middle East makes 17.6 payments (frequency with which the company has to file and pay different types of taxes and contributions), and spends 158 hours (time to prepare, file, and pay three major types of taxes, including labor taxes, mandatory contributions, and consumption taxes) - a figure which is well below the world average, and the lowest for any region. Labor taxes and social contributions account for the largest part of these three indicators in the Middle East, which is quite different from the average global profile. The UAE and Saudi Arabia ranked 1st and 3rd, respectively, in 2013 - up from 6th and 7th in 2012 - while Qatar remained 2nd for the fourth consecutive year (The World Bank, IFC, PwC, 2012).

Dean Kern, Tax Leader at PwC Middle East, concurred that economy in the Middle East feature quite prominently in the top jurisdiction of the Paying Taxes indicators. "This can be largely attributed to the relatively few taxes levied and the reliance on other sources of government revenues. With increased spending requirements and populations demanding greater economic rights, governments in the Middle East will face a challenge to raise additional tax revenues in the future, either by introducing new taxes, expanding the tax base, or increasing tax rates," said Kern in a statement (The World Bank, 2012).

The Director of Global Indicators and Analysis at World Bank Group, Augusto Lopez Claros, further added, "Electronic filing and payment reduces paperwork and complexity in tax systems and can help increase tax compliance and reduce the cost of tax administration" (Nadine Ghannam, 2012).

Low taxes, and their erratic collection, are common features of life in most of the Middle East. For example, taxation accounted for only 5\% of the gross domestic product for the Arab oil producers in 2002, while $17 \%$ for the non-oil producing countries - which is still very low compared to Germany (39\%), Italy (41\%), and Britain (37\%). The main reason, of course, is that many of these countries are rentier economies, where the government has sources of income other than taxes. Oil is a classic example, but there are some others, like Egypt, who benefits in a similar way from the Suez Canal, and several of the poorer Arab countries who receive substantial rent in the form of foreign aid. Overall, slightly less than $20 \%$ of Arab governments' revenue comes from taxes.

As a rule of thumb, high taxes can act as a spur toward democracy and an accountable government. Conversely, low taxes may result in a less accountable and democratic government. The type of taxes levied also affect the coerciveness of accountability. In general, GCC governments rely heavily on indirect taxes - goods, services, and customs duties - rather than the more politically sensitive direct taxes. In 2006, for instance, direct taxes accounted for less than $6 \%$ of Arab governments' revenues. A UN report noted, "This type of tax structure also minimizes the opportunity for citizens to protest against their government. Direct taxes - in particular, income tax - 
are viewed as the category of taxes that give citizens most proof that they are contributing to the public purse. In Arab countries, the majority of tax receipts are derived from indirect sales and customs taxes hidden in the price ... These types of tax typically conceal the direct link between tax payments and funding of the public purse, thus weakening public pressure for accountability" (UNDP. RBAS, 2005). Thus, taxation is not just about raising money. The kind of tax system a country has tells a lot about the relationship between the people and the state.

As the World Bank pointed out last year, raising taxes 1) efficiently requires political effort to secure taxpayers' consent, 2) effectively requires the development of a competent bureaucracy, and 3) equitably requires political concern for the fair and equal treatment of citizens by the state.

\section{DISTRIBUTION OF REVENUES}

For every foreign worker employed, Bahrain started levying a tax on the businesses since 2008. It was a well-planned strategy adopted to increase the cost of employing foreign workers, thereby indirectly encouraging the local businesses to employ more Bahrainis. The money thus collected by the Labor Market Regulatory Authority was used to train the locals for the workplace, create more jobs for them, and thereby supplement local employee wages. Until 2010, the scheme had fetched a whopping BD90 million (\$238 million) which, in turn, will be used to train 20,000 local Bahrainis on low income.

The other GCC countries are closely monitoring this experiment and are planning to replicate them in their own respective countries. Taking the example of Saudi Arabia, the state resources and public sector job creation capabilities are under immense pressure due to the rising population levels. As per the job sector statistics of 2008, only $16 \%$ to $17 \%$ of the local Saudi populations were employed in the private sector. Here also - like the Bahraini attempt, the cost of training the local youths to the required standard can be funded by the businesses. As per the Bahraini officials, this foreign labor tax scheme requires around five years to achieve full success.

\section{FACTORS BEHIND THE GCC TAXATION POLICY}

The following factors forced the GCC states to implement the taxation policy:

- The increasing utilization of the energy export revenues of GCC countries for domestic public welfare

- $\quad$ Threat on future energy export volumes with the increasing domestic energy consumption, thus declining levels of oil production

- $\quad$ Reduction in revenues from trade-related taxation due to increasing numbers of bilateral and/or regional Free Trade Agreements

- Partially since the late 1990 's, due to the recommendations of international institutions to keep up with the economic globalization

- Declining revenues from oil that forced the GCC states to implement the tax system in order to generate more revenues

\section{CONCLUSION}

Economic reform in the Arab countries is not only about promoting development and prosperity. The economic systems are closely linked to the political systems and, in many cases, are intimately bound up with the regime in power.

It is clear that the possibility of introducing various forms of taxation in the GCC states is not a new consideration. However, this issue has been played with for more than twenty years within changing domestic, regional, and international landscapes. With growing populations and expanding economies, the GCC states face increasing challenges to fund their public welfare initiatives and public sector jobs to the same scale as their populations have long been accustomed. As a MP from Kuwaiti Parliament quoted, "Kuwait sells oil to pay salaries, but, in the future, this cannot be practiced."

Taxation is an instrument that can serve - and is already serving - multiple purposes in the GCC region. With this pivotal role of the taxation issue in the changing politico-economic balance, a novel taxation system that 
can help respond to fluctuating oil prices, as well as augment state revenues when faced with increased domestic demand, can be a definite solution. Nonetheless, a question that still remains is, "What would such system be like?"

They tax when you earn a dollar; they tax you when you save it; and they tax you when you invest it. If you earn a dividend, they tax it again, and if you're stupid enough to die, they steal up to half. (Grover Norquist, President of Americans for Tax Reform)

\section{AUTHOR INFORMATION}

Dr. Humoud Almutairi received his Ph.D. in Finance from Durham University, UK (2010) and is an Assistant Professor at Kuwaiti University. Areas of interest are corporate finance, finance management, real estate, banking and management, and capital market.

\section{REFERENCES}

1. Barney, J. (1991). Firm resources and sustained competitive advantage. Journal of Management, 17(1), 92120.

2. Elecon Engineering Company Limited. (2012). 53rd Annual Report 2012-13. Gujarat, India: Elecon.

3. Field, M. (1985). Survey of Bahrain: Economy: Spending to be cut in budgetary squeeze. London: Financial Times.

4. Global Credit Research. (1998). Qatar's Baa2 rating faces short term strain from Natural Gas Projects. New York: Moody's Investors Service.

5. International Monetory Fund. (2001, 07 November). IMF concludes 2001 article for consultation with Saudi Arabia. Washington DC: Public Information Notice No.01/119.

6. International Monetory Fund. (2002, 10 September). IMF concludes 2002 article for consultation with Qatar. Washington DC: Public Information Notice No.02/99.

7. International Monetory Fund. (2003, 11 March). IMF concludes 2002 article for consultation with the United Arab Emirates. Washington DC: Public Information Notice No.03/30.

8. International Monetory Fund. (2001, 29 June). IMF concludes article for consulatation with Kuwait. Washington DC: Public Information Notice No.01/60.

9. International Monetory Fund. (2010, 17 February). IMF executive board concludes 2009 article for consultation with Oman. Washington DC: Public Information Notice No.10/21.

10. Klaus Schwab, M. E. (2008). The global competitiveness report. Geneva, Switzerland: World Economic Forum.

11. Lynch, C. (1999). Competitive advantage: Creating and sustaining superior performance by Michael E. Porter. Cited by Chacarbaghi and Lynch.

12. Mathew, R. (1992, 14 July). Survey of Bahrain: Economic changes add to the strain of adaptation - The prospects for political change. London: Financial Times.

13. Nadine Ghannam, M. A. (2012, 21 November). Tax reforms continue worldwide despite economic turmoil, electronic filing increasing especially. Retrieved April 4, 2014 from http://www.worldbank.org/en/news/ press-release/2012/11/21/tax-reforms-continue-worldwide-despite-economic-turmoil-electronic-filingincreasing-especially

14. Soumitra Dutta, D. B. (2012). Stronger innovation linkages for global growth. In S. Dutta, The Global Innovation Index 2012 (pp. 67-71). France: INSEAD and the World Intellectual Property Organization.

15. The World Bank, I. a. (2012). Middle East remains least demanding Tax Framework. Washington DC: The World Bank.

16. The World Bank, IFC, PwC. (2012). Paying taxes 2013: The global picture. Washington DC: The World Bank.

17. UNDP, RBAS. (2005). The Arab human development report 2004. New York: UNDP, RBAS.

18. World Bank Group and PwC. (2013, 19 November). Paying taxes 2014: The global picture. Washington DC: The World Bank. 


\section{ANNEXURE}

As per the Global Competitiveness Report 2008-2009, the following charts reveal the competitiveness of the GCC States, in general.

\section{U.A.E \\ GLOBAL COMPETITVENESS}

THE MOST PROBLEMATIC FACTOR FOR DOING BUSINESS

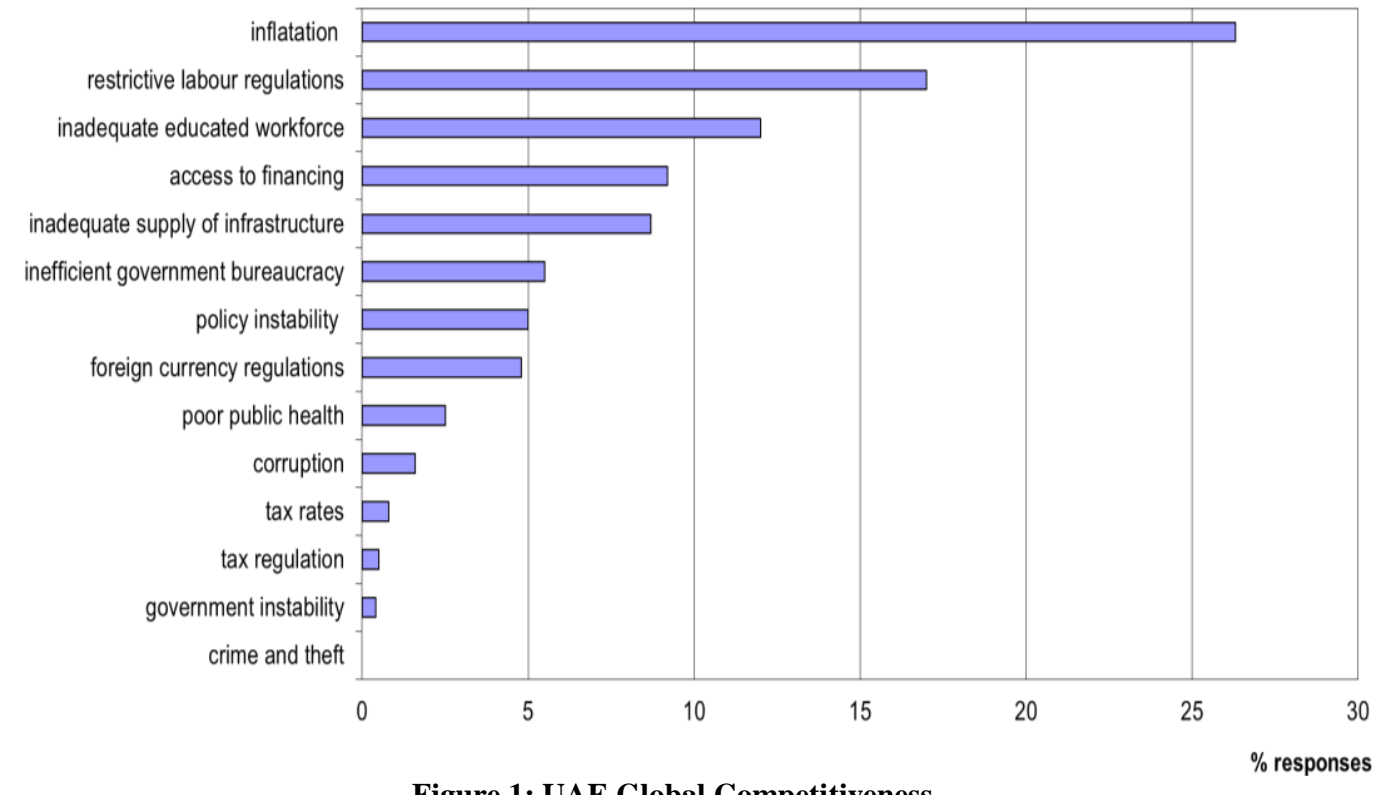

Figure 1: UAE Global Competitiveness

Source: Global Competitiveness Report 2008-2009, Klaus Schwab World Economic Forum, Michael E. Porter Harvard University

K.S.A

GLOBAL COMPETITVENESS

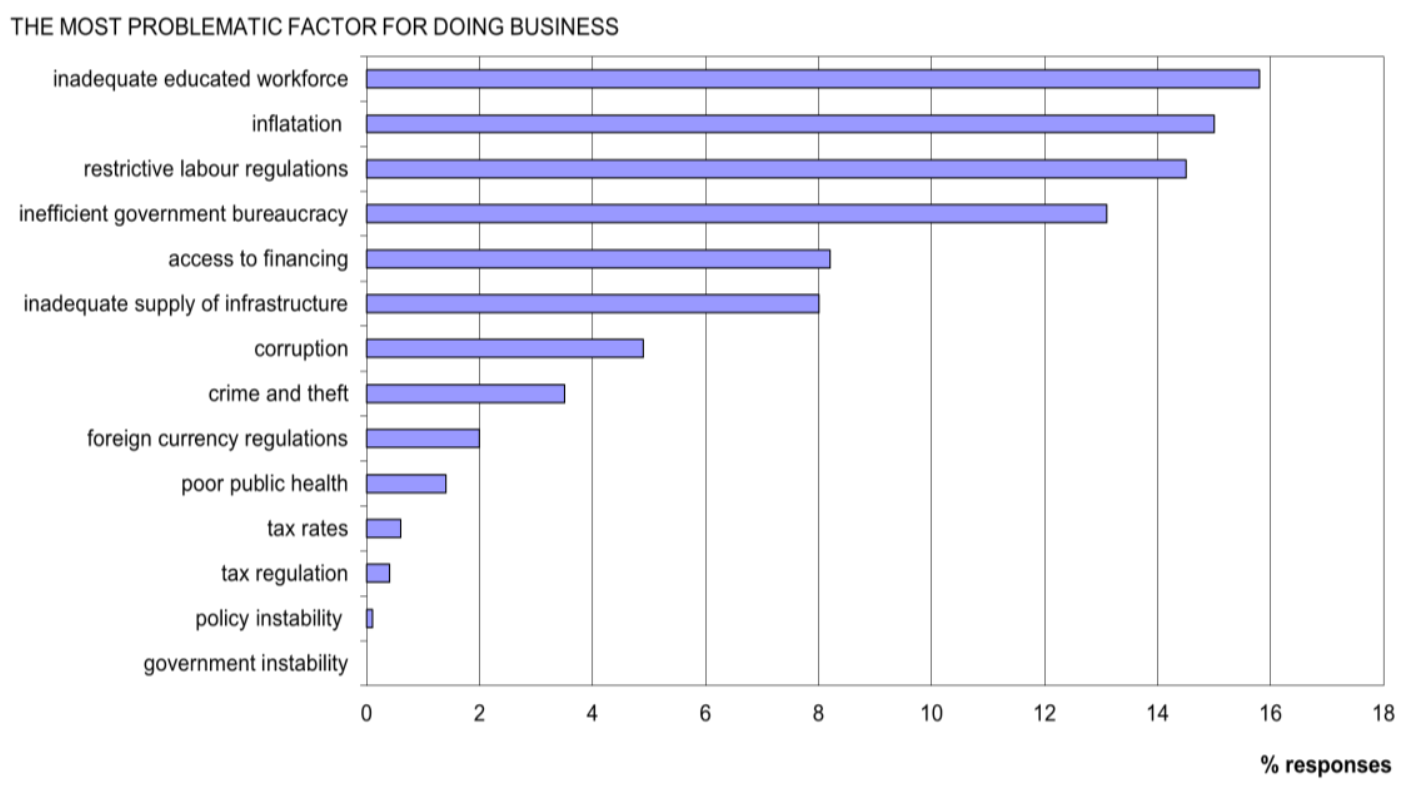

Figure 2: KSA Global Competitiveness

Source: The Global Competitiveness Report 2008-2009, Klaus Schwab World Economic Forum, Michael E. Porter Harvard University 


\section{BAHRAIN \\ GLOBAL COMPETITVENESS}

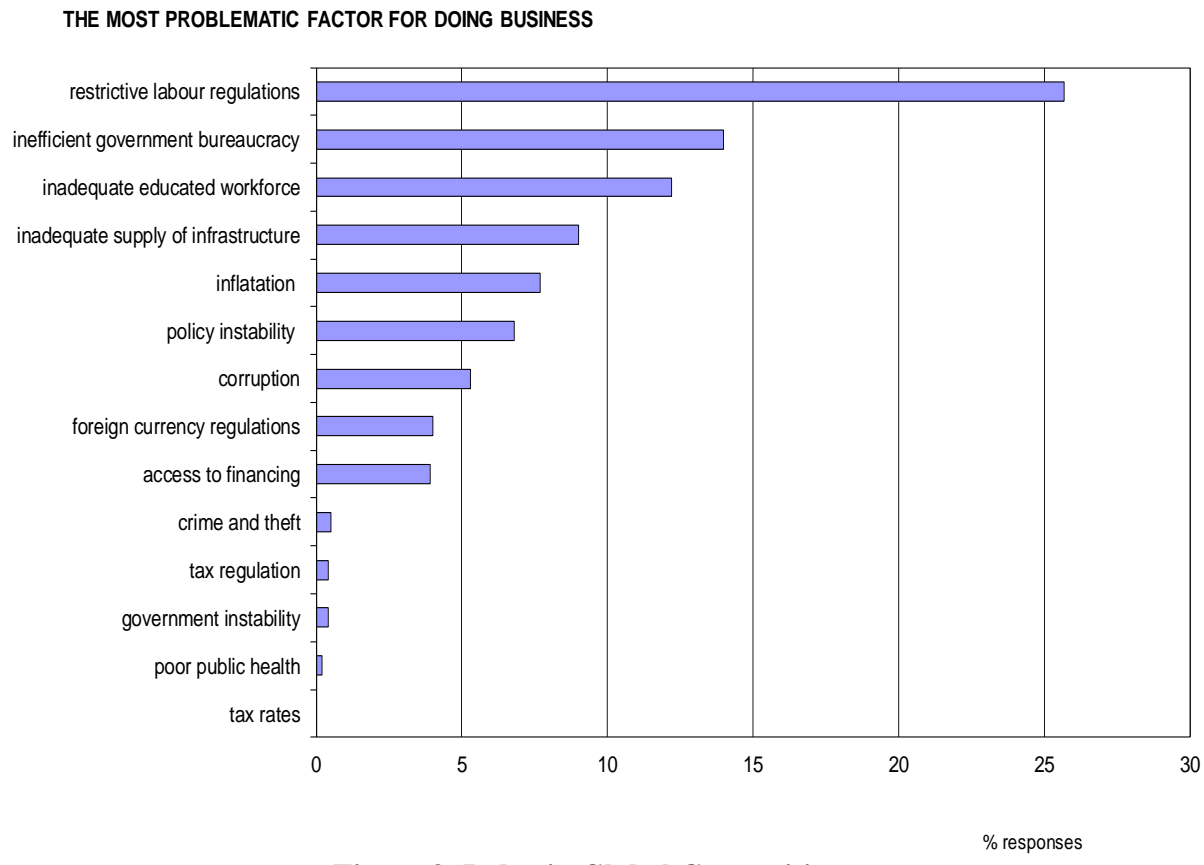

Figure 3: Bahrain Global Competitiveness

Source: The Global Competitiveness Report 2008-2009, Klaus Schwab World Economic Forum, Michael E. Porter Harvard University

KUWAIT

GLOBAL COMPETITVENESS

THE MOST PROBLEMATIC FACTOR FOR DOING BUSINESS

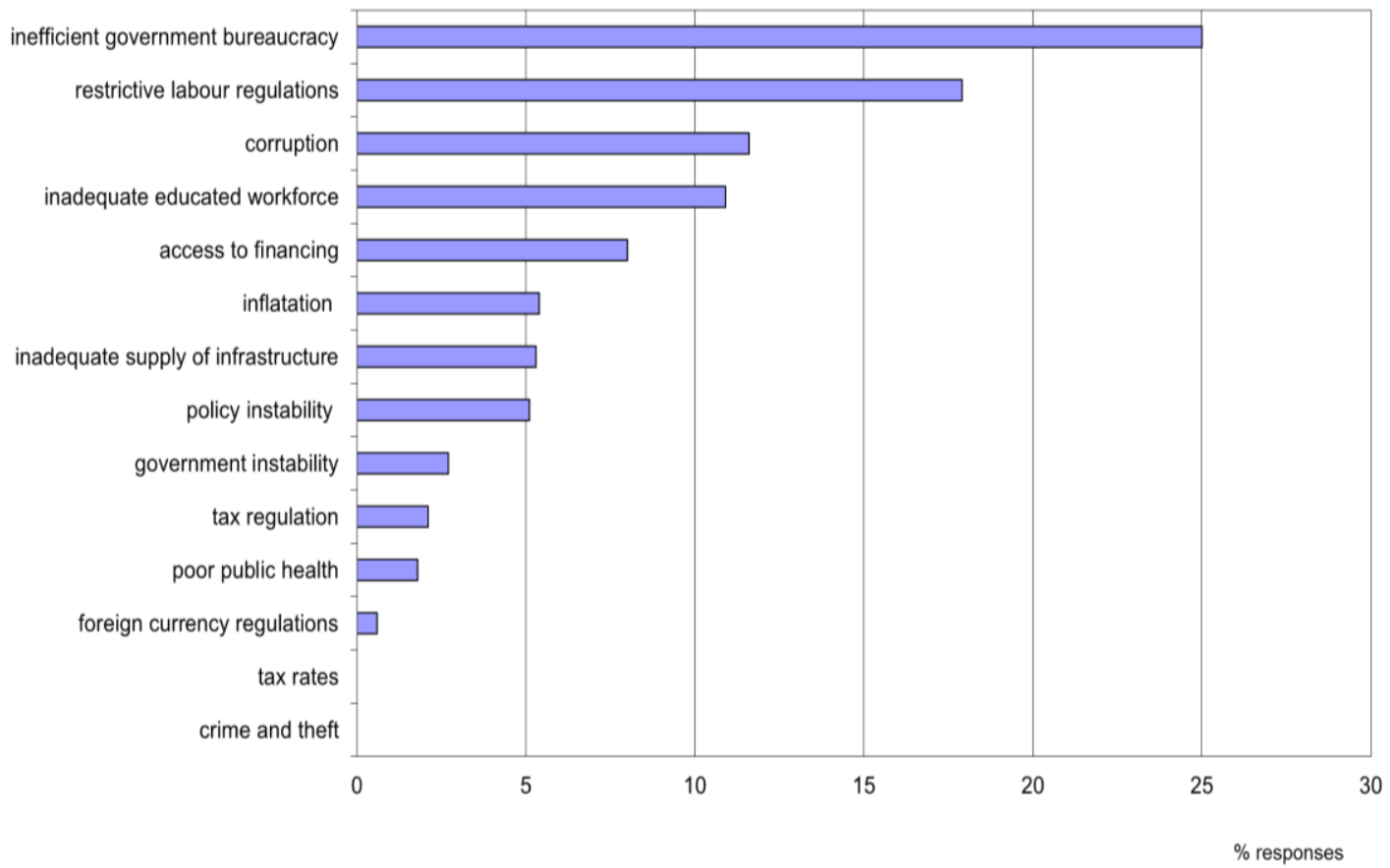

Figure 4: Kuwait Global Competitiveness

Source: The Global Competitiveness Report 2008-2009, Klaus Schwab World Economic Forum, Michael E. Porter Harvard University 


\section{OMAN \\ GLOBAL COMPETITVENESS}

THE MOST PROBLEMATIC FACTOR FOR DOING BUSINESS

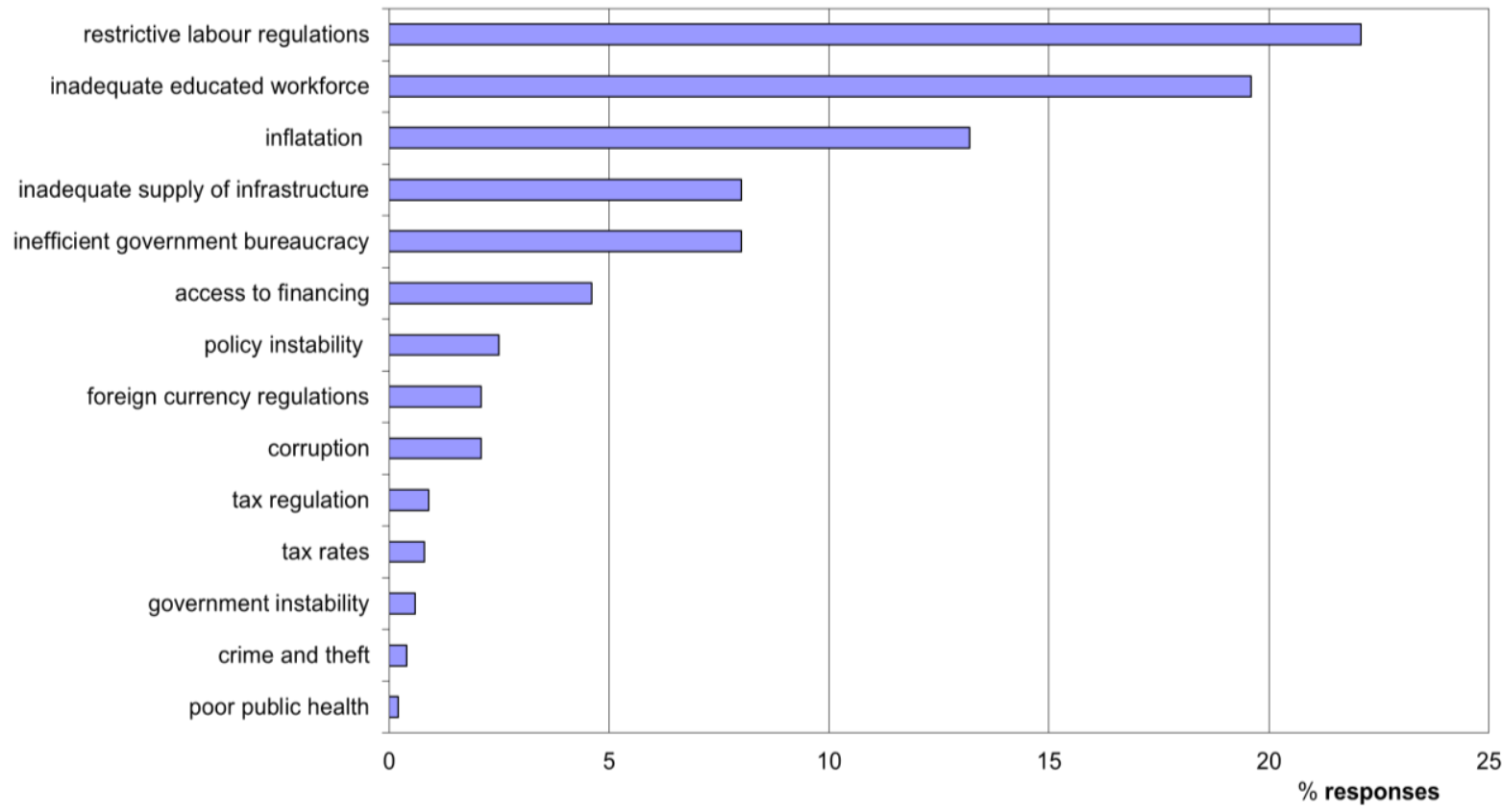

Figure 5: Oman Global Competitiveness

Source: The Global Competitiveness Report 2008-2009, Klaus Schwab World Economic Forum, Michael E. Porter Harvard University

\section{QATAR \\ GLOBAL COMPETITVENESS}

THE MOST PROBLEMATIC FACTOR FOR DOING BUSINESS

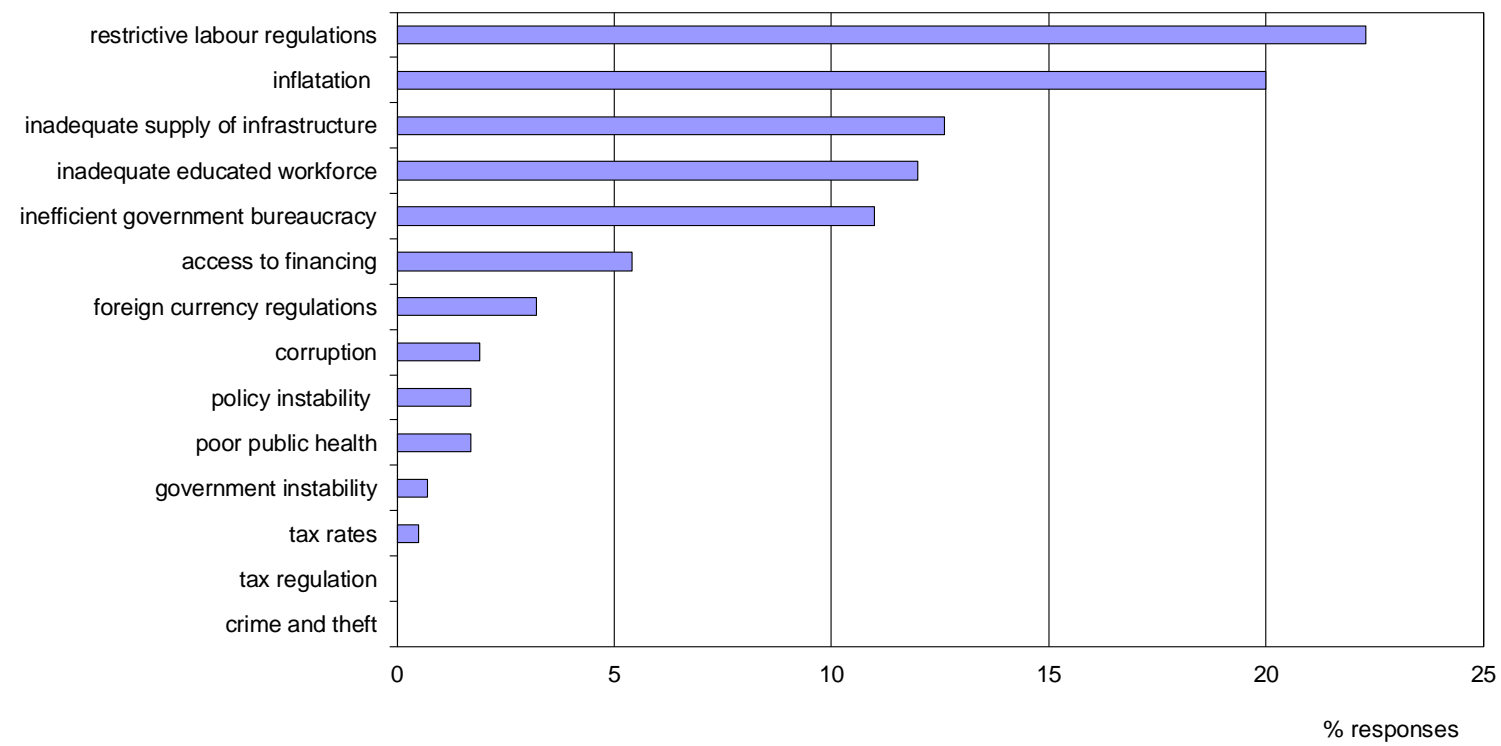

Figure 6: Qatar Global Competitiveness

Source: The Global Competitiveness Report 2008-2009, Klaus Schwab World Economic Forum, Michael E. Porter Harvard University 